Nig. J. Biotech. Vol. 34 (2017) 41-47

ISSN: 01891731

Available online at

http://www.ajol.info/index.php/njb/index

and www.biotechsocietynigeria.org

DOI: https://dx.doi.org/10.4314/njb.v34i1.6

\title{
Haematology and serum indices of broiler starter fed graded levels of raw Pride of Barbados seedmeal
}

\author{
Ogunbode, A. A., Abegunde, P. T., Ayorinde, S. A. and Adelere, R. A. \\ Department of Animal Production Technology, Faculty of Animal and Fisheries Technology, \\ Oyo State College of Agriculture and Technology, P. M. B. 10, Igboora, Nigeria.
}

Copyright resides with the authors in terms of the Creative Commons License. 4.0.
See http://creativecommons.org/licenses/by/4.0/
Condition of use: The user may copy, distribute, transmit and adapt the work, but must recognize the authors
and the Nigerian Journal of Biotechnology.

\section{Abstract}

A study was conducted to evaluate the haematology and serum indices of broiler starter fed graded levels of raw pride of Barbados (Caesalpina pulcherima) seedmeal. Seventy two day old Marshal broiler chicks obtained from Obasanjo Farms, Igboora, Oyo state, Nigeria were randomly assigned into four treatments, each treatment was replicated thrice with six birds per replicate in a completely randomized design, three diets were formulated containing raw pride of Barbados seedmeal at 5, 10 and 15\% levels respectively. Blood samples were collected from six birds per treatment for haematological and six birds per treatment for serum-biochemical indices respectively. Results showed significant $(P<0.05)$ differences for White Blood Cell (WBC $\left.10^{3} \mathrm{U} / \mathrm{L}\right)$, Red Blood Cell (RBC 10 ${ }^{6} \mathrm{U} / \mathrm{L}$ ), Packed Cell Volume (PCV \%) and Haemoglobin (Hbg \%) across the dietary treatments. Total Protein, Albumin, Globulin and Creatinine were significantly $(P<0.05)$ affected by the inclusion of raw pride of Barbados seedmeal in the diets.

Keywords : Broiler starter, haematology, pride of Barbados seed, raw, serum, toxins

\section{Correspondence:+2348062455318, aaogunbode@gmail.com}

\section{Introduction}

Blood is an important indicator of physiological and pathological changes in an organism and has been used in assessing the body's ability to respond to nutritional challenges (Nworgu et al., 2007; Aguihe et al., 2012). Haematological indices are essential in monitoring feed toxicity especially with feed constituents that affect the formation of blood (Aro and Akinmoyegun, 2012) and also provides a means of assessing the internal environment and to understand the causes of the observed physiological indices of an animal under different environmental stimuli. Serum biochemical profiling has been used in several species of domestic livestock to monitor herds and to detect subclinical disease and the selected serum biochemical indices commonly analyzed are serum total protein, albumin, globulin, cholesterol, high density lipoprotein ( HDL), low density lipoprotein (LDL), triglycerides, glucose, urea and creatinine. Evaluation of the blood profile of birds may give some insights as to potential of a dietary treatment to meet the metabolic needs of the birds (Church et al., 1984). The urgent need to curtail the sky-rocketing cost of feed ingredients has prompted nutritionists, farmers and other players in the industry shift research focus to 
alternative feedstuffs, which are locally available, cheap and within the reach of farmers. Pride of Barbados is one of such legume that could be exploited to serve as an alternative source of nutrients in monogastric diets. It grows between 10 feet and 12 feet in height and 6 feet to 12 feet in width. Pride of Barbados is a highly medicinal plant like other legumes and contain considerable nutrients and phytochemicals (Proph et al., 2006). This study therefore, evaluated the effect of raw pride of Barbados seedmeal as unorthodox feed ingredients on the haematological and serum indices of broiler starter.

\section{Materials and Methods}

\section{Experimental Site}

The study was conducted in poultry unit of Teaching and Research Farm of the Oyo state College of Agriculture and Technology, Igboora, Oyo state, Nigeria. The experimental area fall within the humid forest and derived savannah zone of the South western region of Nigeria. The mean annual temperature is $27^{\circ} \mathrm{C}$ and annual temperature range is $8^{\circ} \mathrm{C}-10^{\circ} \mathrm{C}$.

\section{Experimental birds and management}

Seventy two day old broiler chicks were randomly divided into four groups of eighteen birds each. The groups were randomly assigned to four caloric ( $3032.00-3044.00 \mathrm{Kcal} / \mathrm{kg} \mathrm{ME}$ ) and isonitrogenous (23.00 - $23.43 \%$ crude protein ) diets containing four level $(0,5,10$ and $15 \%$ ) of raw pride of Barbados. The composition of the diet is presented in Table 1. Each treatment was replicated three times with six birds per replicate placed in deep litter pens of fresh wood shavings. Feed and water were supplied ad libitum to the birds.

\section{Experimental diets}

The riped virgin pods of pride of Barbados seeds were collected within Igboora between the month of December and January. The mature and riped pods were opened to remove the seed and the seeds were milled using hammer mill and used to formulate four isocaloric and isonitrogenous experimental diets designated as $\mathrm{T} 1, \mathrm{~T} 2, \mathrm{~T} 3$ and T4 containing $0 \%, 5 \%, 10 \%$ and $15 \%$ raw pride of Barbados seedmeal respectively with partial replacement ( nutrient for nutrient) of soyabean.

\section{Chemical analysis}

The experimental diets were analysed for proximate and chemical composition according to the method of AOAC (2005).

Nitrogen Free Extract (NFE) was determined by different and Metabolisable Energy (ME) calculated according to the procedure of Pauzenga (1995) as:

$\mathrm{ME}(\mathrm{Kcal} / \mathrm{kg} \mathrm{DM})=37 \times \%$ Protein $+18.1 \times$ fat + $35.5 \times \% \mathrm{NF}$

\section{Haematology and Biochemical Indices}

Twelve (12) birds in all at the rate of six birds per dietary treatment were selected at the end of feeding trial and bled by the wing vein using hypodermic needle with syringe. Blood was drained into two different carefully labelled bottles for haematological and serum metabolite investigation. The blood samples for haematological parameters were collected into bottles pretreated with ethylene diamine tetra acetic acid (EDTA) an anticoagulant. Blood samples for biochemical indices were collected into another sample bottles containing no EDTA. Packed Cell Volume (PCV), Red Blood Cell (RBC), White Blood Cell (WBC) and Haemoglobin $(\mathrm{Hb})$ was determined by Wintrobe's microhaematocrit, improved Neubauer haemocytometer and cyanometeremoglobin methods respectively. Serum biochemical indices investigated include total protein, albumin, globulin and creatinine.

Quantification of Toxins in Raw Pride of Barbados Seedmeal

Determination of tannins was based on the method of A.O.A.C (1975). Oxalate was determined by the method of Munro and Basir (1969). Saponin content was determined by the modified method of Fenwick and Oakenfull (1981). 
Statistical Analysis

Data obtained were subjected to analysis of variance (ANOVA) using SAS (1999) statistical package. The means were separated using Duncan's Multiple Range Test of the same software.

\begin{tabular}{|c|c|c|c|c|}
\hline $\begin{array}{l}\text { Percentage } \\
\text { Ingredients }\end{array}$ & $\begin{array}{l}0 \% \\
T_{1} \%\end{array}$ & $\begin{array}{l}5 \% \\
T_{2}\end{array}$ & $\begin{array}{l}10 \% \\
\mathrm{~T}_{2}\end{array}$ & $\begin{array}{l}15 \% \\
\mathrm{~T}_{4}\end{array}$ \\
\hline Maize & 48.00 & 48.00 & 48.00 & 48.00 \\
\hline Soyabean meal & 33.00 & 31.35 & 29.70 & 28.05 \\
\hline Raw PBSM & 0.00 & 1.65 & 3.30 & 4.95 \\
\hline Fishmeal & 3.00 & 3.00 & 3.00 & 3.00 \\
\hline Wheat offal & 11.30 & 11.30 & 11.30 & 11.30 \\
\hline Bone meal & 2.00 & 2.00 & 2.00 & 2.00 \\
\hline Limestone & 2.00 & 2.00 & 2.00 & 2.00 \\
\hline Broiler premix & 0.25 & 0.25 & 0.25 & 0.25 \\
\hline Salt & 0.25 & 0.25 & 0.25 & 0.25 \\
\hline L-Lysine & 0.10 & 0.10 & 0.10 & 0.10 \\
\hline $\begin{array}{l}\text { DL - } \\
\text { Methionine }\end{array}$ & 0.10 & 0.10 & 0.10 & 0.10 \\
\hline TOTAL & 100.0 & 100.0 & 100.0 & 100.0 \\
\hline \multicolumn{5}{|l|}{$\begin{array}{l}\text { Determined } \\
\text { analysis }\end{array}$} \\
\hline Dry matter & 90.78 & 90.66 & 90.83 & 90.81 \\
\hline Crude protein & 23.00 & 23.15 & 23.20 & 23.43 \\
\hline Crude fibre & 3.78 & 3.81 & 3.87 & 3.92 \\
\hline Ash & 6.94 & 7.13 & 7.21 & 7.33 \\
\hline Ether extract & 3.61 & 3.65 & 3.69 & 3.73 \\
\hline $\begin{array}{l}\text { Nitrogen free } \\
\text { extract }\end{array}$ & 53.4 & 52.92 & 52.85 & 52.40 \\
\hline $\begin{array}{l}\text { Methabolisable } \\
\text { energy } \\
\text { (Kcal/khom) } \\
\text { calculated } \\
\text { PBSM: Pride of }\end{array}$ & 3044.3 & 3035.0 & 3036.4 & 3032.0 \\
\hline
\end{tabular}

statistical package. The means were

\section{Results}

The determined proximate composition and anti-nutritional factors content of raw pride of Barbados which was used as partial substitute for soya bean meal are in Table 1.

\section{Nutrient composition of experimental diets}

Table 1 shows the gross and the determined compositions of the experimental diets. The highest crude protein $(23.43 \%)$, ether extract $(3.73 \%)$, crude fibre $(3.92 \%)$ and ash $(7.33 \%)$ were obtained in the diet $\mathrm{T}_{4}$. The crude protein, crude fibre, ash and other extract of this diet increased with increasing content of raw pride of Barbados seed meal such that the control diet contained the least values of crude protein (23.00\%), crude fibre (3.78\%), ash (6.94\%) and ether extract $(3.61 \%)$ respectively.

Toxicant composition of raw pride of Barbados seed
Table 2 shows the toxicant composition of the raw pride of Barbados seed. The result revealed raw pride of Barbados seed contain $(0.05 \%)$ tannin, $(0.09 \%)$ phytate, $(0.06 \%)$ oxalate and $(0.28 \%)$ saponin respectively.

Haematology of broilers starters fed raw pride of Barbados based diets

Haematological parameters investigated (Table 3) vis - a - vis white blood cells (WBC), Red Blood Cell (RBC), Packed Cell Volume (PCV) and Haemaglobin $(\mathrm{Hb})$ were significant $(P<0.05)$ affected by the dietary treatments.

Serum metabolites of broilers starters fed raw Pride of Barbados based diets

Table 4 revealed that the serum biochemical indices monitored were not significantly affected by the dietary treatment $(P>0.05)$. 
Table 2: Proximate composition, metabolisable energy and anti-nutritional factors of raw pride of Barbados seed meal

\begin{tabular}{|c|c|}
\hline $\begin{array}{l}\text { Parameters } \\
\text { Dry Matter }(\%)\end{array}$ & $\begin{array}{l}\text { Raw pride of Barbados seed meal } \\
90.64\end{array}$ \\
\hline Crude Protein $(\%)$ & 23.96 \\
\hline Crude Fibre $(\%)$ & 6.81 \\
\hline Ether extract $(\%)$ & 3.96 \\
\hline Ash $(\%)$ & 4.64 \\
\hline Nitrogen Freen Fxtract $(\%)$ & 51.27 \\
\hline Metabolisable Fnergy (Kcal/Kg DM) & 3030.54 \\
\hline \multicolumn{2}{|l|}{ Anti-nutrients } \\
\hline Tannin & 0.05 \\
\hline Phytate & 0.09 \\
\hline Oxalate: & 0.06 \\
\hline saponin & 0.28 \\
\hline
\end{tabular}

Table 3: Haematology of Broilers Starter Fed Raw Pride of Barbados Based Diets

\section{DIETS}

\begin{tabular}{|c|c|c|c|c|c|c|}
\hline \multicolumn{2}{|c|}{ Parameters } & $1(0 \% / 0)$ & $2(5 \%)$ & $3(10 \%)$ & $4(15 \%)$ & SEM \\
\hline $\begin{array}{l}\text { White } \\
\text { Cells } \\
\text { U/L) }\end{array}$ & $\begin{array}{r}\text { Blood } \\
\left(10^{3}\right.\end{array}$ & $18.5^{c}$ & $23.90^{a}$ & $19.40^{b}$ & $23.90^{\mathrm{a}}$ & 2.82 \\
\hline $\begin{array}{l}\text { Red } \\
\text { Cells } \\
u / L)\end{array}$ & $\begin{array}{r}\text { Blood } \\
\left(10^{6}\right.\end{array}$ & $3.52^{a b}$ & $3.44^{a b}$ & $3.26^{c}$ & $3.61^{\mathrm{a}}$ & 0.16 \\
\hline $\begin{array}{l}\text { Packed } \\
\text { Volume }\end{array}$ & $\begin{array}{l}\text { Cell } \\
(\%)\end{array}$ & $28.10^{\mathrm{c}}$ & $31.00^{a b}$ & $29.50^{\circ}$ & 32.00 & 1.32 \\
\hline Haemo & lobin & $9.30^{c}$ & $10.30^{\mathrm{ab}}$ & $10.10^{\mathrm{ab}}$ & $11.05^{\mathrm{a}}$ & 0.48 \\
\hline
\end{tabular}

\section{$(\%)$}

a. b. $c$ means in the same row with different superscripts differs significantly (P < 0.005 ).

Table 4:Serum Metabolites of Broilers Starter Fed Raw Pride of Barbados Based Diets

\section{DIETS}

\begin{tabular}{|c|c|c|c|c|c|}
\hline Parameters & $1(0 \%)$ & $2(5 \%)$ & $3(10 \%)$ & $4(15 \%)$ & SEM \\
\hline $\begin{array}{l}\text { Total } \\
\text { Protein } \\
\text { (g/dI) }\end{array}$ & $4.15^{a b}$ & $3.50^{b}$ & $4.80^{\mathrm{a}}$ & $4.55 a b$ & 0.58 \\
\hline $\begin{array}{l}\text { Albumin } \\
\text { (g/dI) }\end{array}$ & $2.25^{\mathrm{ab}}$ & $2.10^{b}$ & $2.85^{\circ}$ & $2.15^{a b}$ & 1.83 \\
\hline $\begin{array}{l}\text { Globulin } \\
\text { (g/dI) }\end{array}$ & $1.90^{\mathrm{ab}}$ & $1.40^{b}$ & $2.35^{\circ}$ & $1.90^{\mathrm{ab}}$ & 0.32 \\
\hline $\begin{array}{l}\text { Creatinine } \\
\text { (g/dI) }\end{array}$ & $0.55^{\mathrm{ab}}$ & $0.60^{\circ}$ & $0.60^{\circ}$ & $0.50^{a b}$ & 0.07 \\
\hline
\end{tabular}

a. b. c means in the same row with different superscripts differs significantly (P $<0.005)$. 


\section{Discussion}

The dry matter of raw pride of Barbados seed was high $(90.64 \%)$, this shows that the seeds are rich in organic matter. The crude protein of $(23.96 \%)$ for the seed is higher than $(29.00 \%)$ reported for mucuna seed, a wild leguminous plant (Tuleum and Patrick, 2007). The high protein content of the seed may enhance growth and maintenance of tissue. Crude fibre value of $(6.81 \%)$ in the raw pride of Barbados was lower than that reported for raw African Locust bean $(11.7 \%)$ and raw melon seeds $(15.8 \%)$ (Omafuvbe et al., 2004). Fibre diets ease the passage of waste and lowers cholesterol level in the blood. The ether extract of raw pride of Barbados seed (3.96\%) is lower than the value recorded for Bauhinis reticulate which belongs to the pea family (Amoo, 2003). The ash content of raw pride of Barbados is an indication of ranfes of 3.2-4.6 $\mathrm{g} / 100 \mathrm{~g}$ reported for Nigerian underutilized legume flours (Aremu et al., 2006). The nutritional importance of a given feed depends on the nutrient and anti-nutritional constituents (Aletor et al., 1994). The value of phytate in raw pride of Barbados were lower than $234.00 \pm 3.60 \mathrm{mg} / 100 \mathrm{~g}$ DM reported for raw lima beans and lima beans boiled for 160 minutes respectively ( Egbe and Akinyele, 1990). The level of oxalate recorded was below reported value for fresh raw sample of some tropical leafy vegetables like Manihot esculenta, Talinum traingulare and Celosia aregentea (Aletor and Adeogun, 1995). Phytate and Oxalate affect bioavailability of composite nutrients. They complex with bivalent ions like $\mathrm{Ca}^{2+}, \mathrm{Mg}^{2+}, \mathrm{Fe}^{2+}$ and $\mathrm{Zn}^{2+}$ making them unavailable especially in monogastric animals ( Aletor and Omodara, 1994). The tannin content $(0.05 \%)$ in raw pride of Barbados seed is lower than the $(0.42 \%)$ tannin in raw lablab seed (Osman, 2007). The poor palatability associated with high tannin diets can be ascribed to its astringent odour properly by reacting with proteins making them less accessible to the gastric juice of the animals (Ologhobo, 2012).

Saponin content of raw pride of Barbados seed was found to be $(0.28 \%)$ which is within the range of $0.23-0.57 \mathrm{mg} / 100 \mathrm{~g}$ reported by (Abeke et al., 2008). Saponin at high concentration cause cell damage by disrupting cell membranes and consequently arrest cell growth (Ologhobo, 2012). The values of white blood cell obtained in the study are within the normal limit of 9.76$31.00 \times 10^{3} \mathrm{U} / \mathrm{L}$ for normal birds. This is an indication that the birds were free from infection of have built immunity against such infection. There were significant $(P<0.05)$ differences across the dietary treatments for red blood cell values. The values of red blood cells obtained in the study fell within the ranged of 2.5-4.5 x $10^{6}$ U/L reported by McDonald (1996). The packed cell volumes values obtained in the study were in agreement with the range of $29-38 \%$ reported by Iyayi et al., (2008), Iheukwumere and Herbert (2003). All the treatments fell within the range of $24.90-45.20 \%$ for apparently healthy birds reported by Mitruka and Rawnsley (1997), the value of haemoglobin reported by Mitruka and Rawnsley (1997) for normal birds is 7.40- 13.10 $\mathrm{g} / \%$ in which all the haemoglobin values for all the treatment fell within the range. Haemoglobin values obtained are also consistent with the reports of Iheukwumere and Hebert (2003) who reported values of $6.0-13.00 \mathrm{~g} / 100 \mathrm{ml}$. There were significant $(P<0.05)$ differences across the dietary treatment for haemoglobin value. Birds fed $15 \%$ raw pride of Barbados seed meal gave the highest blood total protein. This suggests good quality protein of $15 \%$ dietary level of inclusion for the test feedstuff since the higher the value of the protein, the better the quality of the test feedstuffs (Eggum, 1970).

For albumin, treatment four (4) gave the highest value $(3.20)$ that was significantly $(p<0.05)$ different from other diets. This contributes to its higher ability to act as a clothing factor and hence prevent haemorrhage (Robert et al., 1993) than other diets. Globulin results showed significant $(P<0.05)$ difference. This implies that all the diets have the ability to fight against diseases ( Eggum, 1970) but diet 2 had a better ability than others because of its observed highest value. The least value of $(0.50)$ were obtained in the pride of Barbados based diets $\left(T_{2}\right.$ and $T_{3}$ ) and since the lower the value of creatinine, for a particular test feedstuff, the better the protein quality (Ologhobo et al., 1993). 


\section{Conclusion}

This study has demonstrated that raw pride of Barbados seedmeal possess good dietary protein quality for optimal growth of broiler starter. However, the results revealed that feeding raw pride of Barbados seedmeal above $15 \%$ to broiler starters will significantly alter the haematological and serum indices .

\section{References}

A. O. A. C. 2005 . Official Method of Analysis. $18^{\text {th }}$ Ed. Association of Analytical Chemists, Arlington, Virgina.

A. O. A. C. 1975 . Official methods of analysis of the Association of Official Analytical Chemists, Washington, D.C.

Abeke, F. O., Ogundipe, S. O., Dafwang, I. T., Sekoni, A. A., Abu, A. and Adeyinka, I. A. 2008. Effect of duration of cooking on the level of some anti-nutritional factors of nine varieties of lablab purpureus beans. Nig. J. of Anim. Prod. 35 (2): $217-223$.

Aguihe, P. C., Kehinde, A. S. and Iwu, C. J. 2012. Haematological and Serum biochemical indices of broiler fed local groundnut cake meal as a replacement for Soyabean meal. Proceedings of the $17^{\text {th }}$ Annual Conference of Animal Science Association of Nigeria. 9 13, 2012. Abuja. Pp. 412- 415 .

Aletor, V. A. and Adeogun, O. A. 1995.Nutrient and anti-nutrients components of some tropical leafy vegetables. Food Chem. J. 53: 375379.

Aletor, V. A. and Omodara, O. A. 1994.Studies on some leguminous browse plants with particular reference to their proximate, mineral and some endogenous anti-nutritional constituents. Anim. Feed Sci. Tech. 46: 343 - 348.

Aletor, V. A., Goodchild, A. V., Moneim, E. L. and Abd, A. M. 1994. Nutritional and anti-nutritional characteristics of selected Vicia genotypes. Anim. Feed Sci. Tech., 47:125 - 139.

Amoo, I. A. 2003. Effects of fermentation on the nutrient and nutrient content of Bauchinia reticulate. J. Res. Sci. Mgt. FUTA, Akure. 1: 13 16
Aremu, M. O., Olaofe, O. and Akintayo, T. E. 2006. A comparative study on the chemical and amino acid composition of some Nigeria underutilized legume flours. Pak. J. Nutr. 5: 34 38.

Aro, S. O. and Akinmoyegun, M. B. 2012. Physiochemical attributes of wine produced from the yellow pulp of Parkiabioglobosa using traditional Juice extraction technique. Nig. Food. J. 19: Pp. 76 - 79.

Church, J. P., Judd, J. T., Millers, S., Young, C. W., Kebay, J. L. and Kin, W. W. 1984. Relationship among dietary constituents and specific serum clinical components of subjects eating self selected diet. American Journal of Nutrition.40:1338-1344.

Day, R. A. and Underwood, A.L. 1986.Quantitative Analysis. ${ }^{\text {th }}$ ed. Prentice Hall Publication. Pp. 701.

Egbe, I. A. and Akinyele, I. O. 1990.Effect of cooking on the anti-nutritional factors of lima beans (Phaseolus lunatus). Food Chem. 35: 81 87.

Eggum, B. O. 1970. Blood urea Measurement as a technique for assessing protein quality. $\mathrm{Br}$. J. Nutr. 24: 983 - 988.

Fenwick, D. E. and Oakenfull, D. 1981. Saponins content of soyabeans and some commercial soyabean products. J. Sci. Food Agric. 32 : 273 278

Iheukwemere, F. C. and Hebert, V. 2008. Physiological responses of broiler chickens to quantitative water restrictions. Int. J. Poult. Sci. 2: 117 - 119.

Iyayi, E. A., Taiwo, V. O. and Fagbohun, A. O. 2008. Performance, carcass characteristics, histopathogical studies of broilers fed Mucuna utilis bean meal based diets. Israel J. Vet. Med. 28: $1-5$.

Mitruka, B. M. and Rawnsley, H. N. 1977.Clinical Biochemical and Haematological Reference Values in Normal Experimental Animal. Masson, New York. 
Munro, and Basir, O. 1969. Oxalate in Nigeria vegetables. W. Afri. J. Biol. Appl. Chem, 12 : 14 18

Nworgu, F. C., Ogungbenro, S. A. and Solesi, K. S. 2007. Performance and some Blood Chemistry Indices of Broiler Chicken Served Fluted Pumpkin (Telferia occidentalis) leaves extract supplement. American European Journal of Agriculture and Environmental Science 2(1): pp. 90 - 98.

Ologhobo, A. D. 2012. Feed Bio hazards: life destroyers and life enhancers. An inaugural lecture delivered at the University of Ibadan on $6^{\text {th }}$ September, 2012.

Ologhobo, A. D., Apata, D. F. and Oyejide, A. 1993. Utilization of raw jackbean (Canavalis ensiformis) and jackbean fractions in diets for broiler chicks. Br. Poult. Sci.34:323 - 337.

Omafuvbe, B. O., Falade, O. S., Osuntogun, B. A. and Adewusi, S. R. A. 2004.Chemical and biochemical changes in African Locust Bean (Parkiabiglobosa) and melon (Citrillus) seeds during fermentation to condiments. Pak. J. Nutr. 3: 140 - 145.

Osman, M. A. 2007. Effect of different processing methods in nutrient composition, anti-nutritional factors and in-vitro protein digestibility of Dolichos Lablab bean. Pak. J. Nutr. 6 (4): 299 303.
Pauzenga, U. 1985. Feeding parent stock. Zootechnica International, December, 1985. Pp. $22-24$

Price, M. L., Socoyoc, S. V. and Butter, L. G. 1978. A critical evaluation of the vanillin reaction as an assay for tannin in sorghum grain. Agric. Food Chem. 28: 1214 - 1218

Proph, T. P., Madusha, A. O., Onoagbe, I. O., Inegbenebor, U. and Okoli, R. I. 2006. Effects of Aqueous leaf extract of pride of Barbados (Caesalpinapulcherrima) on the activities of some liver functions enzymes and blood glucose concentration in normal rabbits. Pak. J. Nutr. 5: $410-413$.

Reddy, M. B. and Love, M. 1999. The impact of food processing on the nutritional quality of vitamin and mineral. Adv. Exp. Med. Bio. 459: 99 $-106$

Robert, K., Murray, Darylk, Grammer, P. A., Mayes, Victor and Rodwell, W. 1993.Narpers Biochemistry 23 edition. Pp. 665763.

SAS Institute 1999. SAS/STAT. User's Guide Version 8 for Windows SAS Inst. Inc. Carry, North Carolina, U.S. A.

Tuleum, C. D. and Patrick, J. P. 2007. Effect of duration of cooking Mucuna utilis seed on Proximate analysis, levels of anti-nutritional factors and performance of broiler chickens. Nig. J. of Anim. Prod. 34 (1): 45 - 53. 